\title{
CENTENNIAL ANNIVERSARY OF PROF. CARLOS DA SILVA LACAZ (1915-2015)
}

\author{
Ricardo NEGRONI(1)
}

I greatly appreciate the honor granted to me by the Revista do Instituto de Medicina Tropical de Sao Paulo to write an editorial to this special issue, a tribute to Professor Carlos da Silva Lacaz.

Professor Lacaz was born in Guaratingueta, Sao Paulo State, Brazil, on September the $19^{\text {th }}, 1915$. He attended primary and high school in his home town. He was a pupil of his own father Rogerio da Silva Lacaz, a teacher of mathematics, algebra, geometry and trigonometry, from whom he inherited his teaching vocation, his love of science and a deep sense of ethics. He had a sister and four brothers, all of them outstanding teachers in their fields. One of them was also a plastic artist and other a virtuose performer of "cavaquinho" (a small guitar of Portuguese origin). In 1943 he married Dinah Maria Martins, since then his inseparable partner, with whom he had four children.

In 1934 he entered the School of Medicine of Sao Paulo University and during the third year of the medical school he joined Professor Floriano Paulo de Almeida who was the full professor in the Microbiology

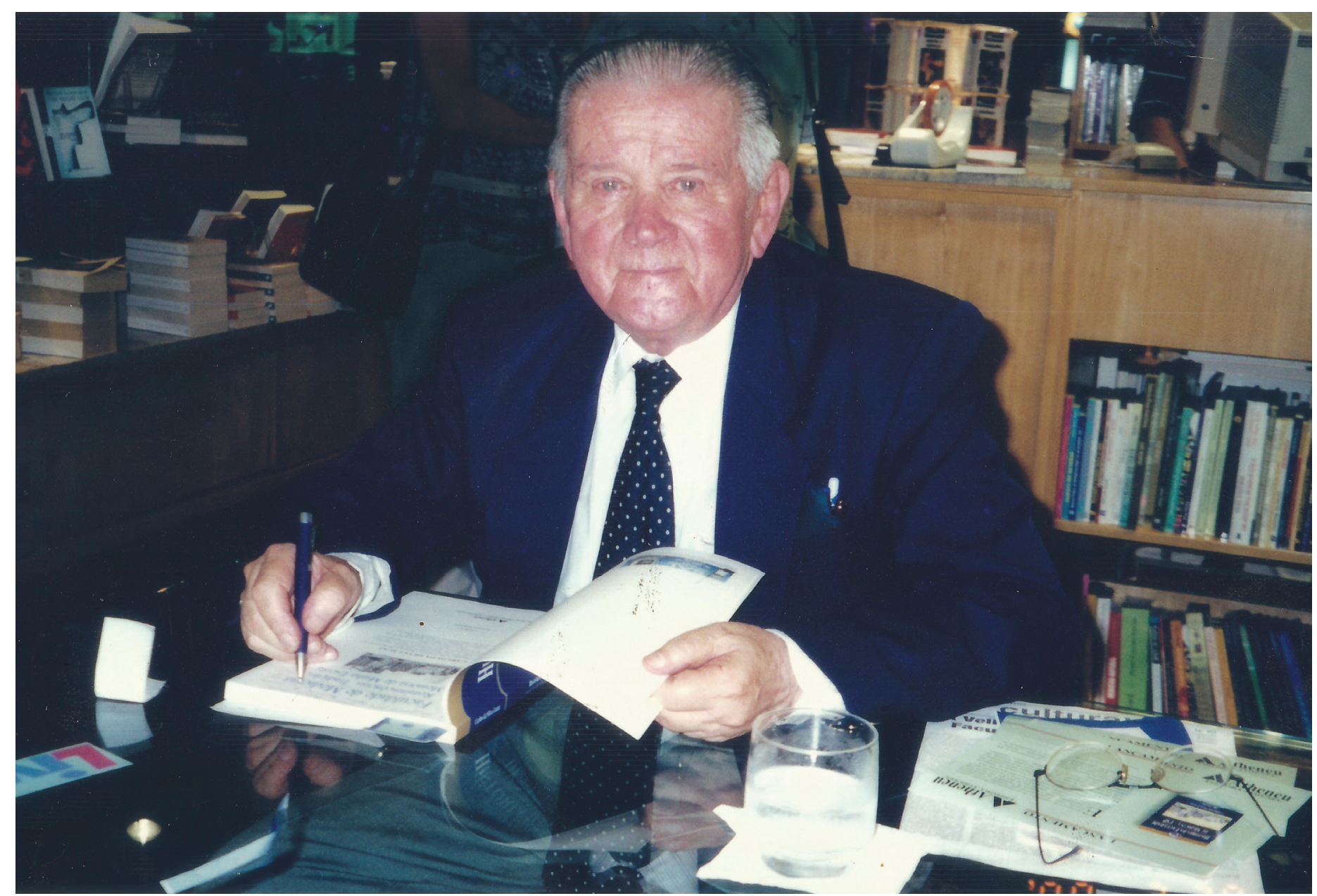

Prof. Dr. Carlos da Silva Lacaz 
and Immunology Department. Professor Almeida led him to study Mycology. He graduated from the School of Medicine in 1940 being honored as the best student of his class. It must be pointed out that this Medical School was rated as "A-level" by the American Medical Association in 1951.

In 1953 Professor Lacaz won the contest to become the Microbiology and Immunology Full Professor at Sao Paulo School of Medicine, where he was once its dean (1974-1978) and its vice-dean twice. He was also Head of the Nursing School.

In 1959 he created the Sao Paulo Institute of Tropical Medicine which he directed until 1985. He founded the Journal of the Sao Paulo Institute of Tropical Medicine, a bimonthly publication of high scientific level. Between 1970 and 1983 he took part in meetings about mycosis sponsored by the Pan American Health Organization, which greatly contributed towards the improvement of the scientific level of Medical Mycology in America.

Professor Lacaz' contributions to Mycology have been internationally acknowledged. He was awarded the doctor "honoris causa" degree by several universities in Brazil and in other countries. He received the Rhoda Benham Medal of the Medical Mycology Society of the Americas in 1977, and the Lucille George Award of the International Society for Human and Animal Mycology in 1988. In 1999, Paulo Taborda, Valeria Taborda and Michael McGinnis identified a new genus of fungi while studying the causative agent of Lobo disease which they named Lacazia loboi in his honor.

In 1969 Professor Lacaz strongly opposed the transfer of the Microbiology and Immunology Department to the University campus because he thought this would prevent medical students to get in contact with disciplines such as Physiology, Biochemistry, Microbiology and Immunology, among others. As he was not able to stave this intervention off he was appointed head of the Mycology sector of the Dermatology Department and of the Institute of Tropical Medicine. He was in charge of the annual course of Dermatological Mycology, and the prestigious specialization course in Tropical Medicine, and also took over the Museum of History of Medicine. He also held the post of Secretary of Health in Sao Paulo Municipality.

His contributions to Medical Mycology can be appreciated in more than 500 scientific publications and in several books, which include: Lacaz: Tratado de Micologia Médica, O grande Mundo dos Fungos, Temas de Moléstias Infecciosas e Tropicais, Geografia Médica do Brasil, Guia para Identificacão de Fungos, Actinomycetos, Algas.

I met Professor Lacaz at the age of six. He was studying Actinomycetales with my father at the Malbran Institute in Buenos Aires. We started a friendship that only ended with his death on April the $23^{\text {rd }}, 2002$. In 1964, I was his student in the specialization course in Tropical Medicine where I was able to appreciate his most important virtues: his vast knowledge, his teaching vocation, his organizational capacity and his leadership. I was fascinated by that course and I have used it as a model for my teaching activities throughout my long career as a university professor.

So that readers can understand what Lacaz was like, I transcribe below the preface to the 1967 edition of Lacaz: Compêndio de Micologia Médica written by my father (Pablo Negroni): "Carlos da Silva Lacaz is a tireless worker with a vast mycological experience acquired through his contact with patients and enriched by his lab research in the Immunology and Microbiology Department and in the Institute of Tropical Medicine which he heads. Lacaz excels in his organizational capacity, he is very active and meticulous in his work, very intelligent and remarkably gifted for original creative investigation. He has written hundreds of works on all the subjects related to Medical Mycology, among which the ones on South American blastomycosis, immunology and treatment of mycosis stand out."

Lacaz has left numerous pupils of a high scientific level and others who, like me, apply his teachings in the best possible way. 